\title{
Exploring Experienced Teachers' Constructions of Culturally and Linguistically Diverse Students in an Online Class
}

\author{
Amber N. Warren \\ University of Nevada, Reno \\ U. S. A.
}

\begin{abstract}
This article examines online discussions during a teacher education class for experienced teachers seeking licensure in teaching English learners. It seeks to understand experienced teachers' constructions of culturally and linguistically diverse (CLD) students. Using discourse analysis to emphasize talk as situated and action-oriented, the article indicates how belief claims expressed during experienced teachers' online discussions construct specific versions of what it means to be a CLD student. Findings further suggest that participants managed their authority to speak about students' needs in patterned ways. These findings have implications for teaching and learning, particularly for the preparation of experienced teachers.
\end{abstract}

KEYWORDS: teacher education, online class, linguistically diverse, English learners, discourse analysis

\author{
Literature Review \\ Theoretical and Methodological Framework \\ Data Sources and Analytical Procedures \\ Findings \\ Discussion and Implications \\ References \\ Author Contact \\ Appendix A: Table of Example Extracts for Codes
}

Between 1990 and 2010, the population of students for whom English was not their first language increased 80\% (Pandya, Batalova, \& McHugh, 2011). This English learner (EL) student proliferation in schools around the United States means that more teachers are becoming teachers of culturally and linguistically diverse (CLD) students. Thus, many teachers who have received little-to-no training in working with CLD students are responsible for meeting the needs of these students. Though few jurisdictions currently require such coursework for all teachers (Ballantyne, Sanderman, \& Levy, 2008), teachers need to continue gaining skills to support CLD students throughout their careers (Lucas \& Villegas, 2013, p. 98). Practicing teachers are willing to seek out training for working with EL students, and they perceive this education as valuable (Ardasheva \& Brown, 2011). When inservice teachers return to the teacher education classroom seeking EL teaching certification, it is critical to understand how their prior experiences as teachers affect their interactions as teacher-learners. However, most research is focused on pre-service, rather than practicing, teachers (Gay, 2014). There have 
been few studies of practicing teachers engaged in coursework (Daniel \& Pray, 2016; Webster-Wright, 2009).

This paper examines experienced teachers' beliefs about CLD students, specifically English learners (ELs), within an online teacher education class, with the goal of understanding how the teachers' forum discussions position "being" an EL student and "doing" EL teaching in particular ways. It is grounded within discursive constructionism - a theoretical stance that recognizes discourse as the fundamental medium for social action and emphasizes the importance of analyzing discourse (talking or writing) to understand the construction of identities, social actions, and meanings (Potter \& Hepburn, 2008). Methodologically, this study is informed by discursive psychology (DP) (Potter \& Wetherell, 1987). This DP orientation enabled me to interpret participants' belief claims as discursive, emphasizing the way that beliefs-a historically internal construct-are socially, actively, and relationally developed in interaction. Specifically, I focus on (a) what belief claims about EL students were made visible through experienced teachers' "talk" online and (b) how these claims to belief were structured and accounted for during the online discussion. Finally, I consider the role of teacher educators in engaging inservice teacher-learners in attending to the practical consequences of such talk for the EL students framed by this discursive positioning.

\section{Literature Review}

Beliefs play a profound role in the framing of teachers' assumptions about teaching, students, and the material to be taught (e.g., Johnson, 1994; Pajares, 1992). For instance, it is generally accepted that teachers' beliefs provide a basis for action (Borg, 2011) and influence their orientations as teachers (Fives \& Buehl, 2012). Studying teacher beliefs about CLD students is critical because teachers' beliefs about ELs or other students who may differ from the assumed "mainstream norm" have practical—often negative-consequences for these students (Lucas, Villegas, \& Martin, 2014, p. 453).

\section{Beliefs and Teacher Education}

Experienced teachers bring with them an array of experiences that shape how they orient to the practices and information presented in teacher education courses. Indeed, teachers' beliefs about working with CLD students have been cited as an important factor in their ability to teach to and for diversity (Gay, 2010; Palmer \& Henderson, 2016). The teacher education classroom itself may be a formative site in shaping teachers' beliefs about working with CLD students. Studies show positive changes to teachers' beliefs about their readiness to work with students learning English due to experiences in teacher education classrooms (e.g., Coady, Harper \& de Jong, 2011; Jimenez-Silva, Olson, \& Hernandez, 2012). 
However, other research indicates that experienced teachers' beliefs are less subject to change (Gatbonton, 2008). Regardless, consensus holds that experiences in teacher education programs are connected to teachers' beliefs and their practices as classroom teachers (Kyles \& Olafson, 2008).

Especially for mainstream teachers, courses in EL pedagogy, language acquisition, and cultural and linguistic diversity are important for developing teachers' knowledge about EL learners (de Courcy, 2011). These courses, further, are positively associated with teachers' self-efficacy beliefs about their EL teaching practice (Flores \& Smith, 2009). For example, graduates of a teacher education program designed to infuse CLD teaching practices into all education courses reported generally positive outcomes regarding their feelings of preparedness to work with diverse learners upon graduation (de Jong, Harper, \& Coady, 2013). These graduates reported feelings of efficacy with respect to teaching practices like providing wait time, although they reported concerns with other effective practices such as bilingual proficiency.

Not all studies looking for positive change in teachers' beliefs have found that such transformation occurs. One study examining the beliefs and practices of two beginning teachers showed that even after significant training teachers implemented only a limited range of strategies appropriate to facilitating EL students (Coady, Harper, \& de Jong, 2016). Similarly, despite considerable professional development, teachers report a lack of familiarity with concepts related to CLD teaching and intervention (Doran, 2017). A study by Gleeson and Davidson (2016) analyzes interview and questionnaire data from practicing teachers in Australia and shows that "teachers did not readily accept professional learning outside their existing epistemology" (p. 43). Instead, they suggest that any visible change can be attributed mainly to the influence of colleagues. These findings, while troubling for teacher education, highlight the potential that peer interactions have for influencing the ways that teachers talk about their beliefs regarding working with CLD students. Thus, understanding how teachers talk to one another about their beliefs regarding EL teaching is important to teacher educators interested in coordinating interactions that might lead to challenging deficit constructions and adopting asset-oriented ways of talking.

\section{Beliefs about Teaching English Learners}

A substantial body of research over the past 50 years has focused on beliefs and attitudes about multilingual or CLD students (Fives \& Buehl, 2012). Many studies identify misconceptions teachers hold as one potential challenge in changing teachers' beliefs. For example, a survey of subject-area high school teachers finds misconceptions about how languages are learned (Reeves, 2006). Similarly, the findings of Karabenick and Noda (2004) demonstrate extensive variability in teachers' survey-reported attitudes about EL students, bilingualism, and the value of promoting home language proficiency. Further, teachers who are 
very successful by external measures (e.g., students' progress) may still hold deficit views about their students' home languages (Hertzog, 2011).

A literature review of mainstream teachers' beliefs about multilingual learners shows that teachers' beliefs are tightly connected to their practice, and that factors including training, years of experience, and experience with language diversity all play a role in teachers' beliefs (Pettit, 2011). Although inservice teachers expressed awareness of the need to draw on students' cultural background when teaching, most fail to differentiate (Rizzuto, 2017). Some studies find that content area teachers feel no obligation to provide modifications to language learners (Bryan \& Atwater, 2002). Other work indicates that teachers are concerned about the lack of tools or time necessary to meet the needs of diverse learners (Gándara, Maxwell-Jolly, \& Driscoll, 2005). Additional studies identify teachers' feelings of being underprepared to meet the needs of EL students (Polat, 2010) including those with special needs (Chu \& Garcia, 2014). While teachers are cognizant of some issues that CLD students face (i.e., cultural mismatch between home and school), they also reproduce dominant discourses in their statements of beliefs about native language use and parents' lack of involvement as hindrances to students' academic success (Shim, 2014).

By examining teachers' forum discussions within one teacher education course, this study seeks to understand how everyday classroom interactions work to enable the very linguistic constructions that critically-oriented education researchers seek to change, and to understand how these deficit constructions are made "real" within the ongoing interaction of the classroom. Although this study is focused on deficit constructions, the analysis is not intended to shame the teachers in this study, nor the efforts of teacher educators. Rather, it is an attempt to understand what "goes on" in classroom interaction, with an eye toward ameliorating everyday linguistic practices that may promulgate such negative constructions.

\section{Theoretical and Methodological Framework}

This study is situated in an approach to discourse analysis known as discursive psychology (DP) (Potter, 2012). This approach provides a theoretical grounding in a view of discourse as action and a methodological approach that employs discourse analysis with an emphasis on conversation analytic techniques. DP begins with the assumption that "discourse is the fundamental medium for human action" (Potter, 2012, p. 4) and views discourse as both situated and actionoriented (Edwards \& Potter, 2001). A DP approach highlights the socially contingent nature of talk. It emphasizes the ways that discourse is purposefully and rhetorically constructed within the constraints of a particular context and that discourse shapes, and is constructive of, that communicative context.

It also differentiates itself by its epistemic stance toward knowing. In DP, cognition (e.g., knowing, beliefs) is presumed as being made "visible" in 
participants' discursive practices, rather than oriented to something "inside the head." This does not mean that this study takes a person's mental state to be nonexistent; rather, it allows for the treatment of discourse as primary. The use of conversation analysis (CA) (Sacks, 1992) alongside DP provides an analytical approach grounded in the participants' own words and oriented to what that language is doing. As a post-cognitive approach to discourse analysis, DP offers teacher education researchers a means of exploring how teachers' beliefs are claimed and displayed in interaction.

By considering how belief claims are constructed for specific purposes and constructive of the interactional context, this study emphasizes that claims are "interactional objects at work within situated practice" (Lester, 2011, p. 287). From this standpoint, then, data were approached with an eye toward what the inservice teachers were rhetorically constructing with their belief claims and the linguistic resources they drew upon to achieve this.

\section{The Case for a Discursive Psychology (DP) Approach to Teacher Beliefs}

Most research on teacher beliefs starts with a conceptualization of beliefs as held within the teacher's mind-sometimes affected by social circumstances, but still with a private, mental component. Fives and Buehl (2012) defined beliefs as "individually held conceptions that are in constant relation to the context and teachers' experiences" (p. 476). This view is apparent in the findings and methods of many studies, which largely consist of interviews, observations, surveys, and reflections in which attempts are made to connect the observations of researchers and teachers' mental states. Efforts to clean up the "messy" construct of beliefs over the decades have proven elusive. Still, it is largely agreed upon that the study of beliefs has great potential to inform educational practice.

The turn toward the social aspects of learning and theories of situated cognition has been enormously influential to the fields of second language studies and EL teacher education. This perspective has allowed researchers to consider knowledge as developed through more than simply a process-product relationship and through "a broader epistemological view of ESOL teacher education...that accounts for teaching as it is learned and as it is practiced" (Freeman \& Johnson, 1998, p. 397). However, in most studies, beliefs are still presented as though the research has access to these mental processes. In other words, these studies employ a representational view of language-one in which teachers' words "are taken as isomorphic to their mental worlds... assumed to capture their thoughts, beliefs, knowledge, and feelings" (Freeman, 1996, p. 734). Language-based approaches, such as conversation analysis (CA) and discursive psychology (DP), offer a way to embrace the "messiness" of talk-in-interaction by staying close to teachers' own words (Warren, 2018). The micro-analytic focus common to CA and DP is useful in making sense of teachers' beliefs at the sites of their construction. By viewing the relationship between discourse and teachers' mental lives as situated and action-oriented (Edwards \& Potter, 2001), research and teaching are 
able to gain "access to everyday acts that are often presumed to be 'internal' and difficult (if not impossible) to access" (Oreshkina \& Lester, 2015, p. 425).

However, there is a limited body of research using discourse analysis, and specifically DP, to understand teachers' beliefs as discursively constructed. Barker and Rossi $(2011,2012)$ examined interpretive repertoires, or cultural ways of making meaning (Wetherell, 1998) employed by physical education teachers in describing their beliefs about teamwork. They found that teachers used a variety of repertoires in constructing recognizable stances toward teamwork and argued for a DP approach to beliefs as a means of understanding how teachers made sense of what they did to improve pedagogical knowledge. Oreshkina and Lester (2015) used DP to examine pre-service teachers' written reflections. They found that students' reflections displayed "compliance with institutional expectations" and that a predominant pattern of interaction involved "legitimating [their] identities as knowledgeable and valid speaker/writers" (p. 7). In other words, the institutional expectations for reflecting on beliefs shape how the students frame their reflections, and this is evident in the students' writing. These findings are suggestive of the usefulness of a DP approach for understanding beliefs as produced in and through ongoing interaction.

\section{Research Questions}

The research described here is part of a larger study that sought to identify how belief claims about second language teaching practices are discursively constructed and displayed by teachers in an online class. Specifically, this paper investigates how experienced teacher "talk" about CLD students and the teaching of EL learners constructs specific versions of what it means to be a linguistically diverse learner. To understand this issue, I focus on two questions:

1. What beliefs about EL students are visible in experienced teachers' "talk" online?

2. How are these beliefs structured and accounted for within the online discussion?

\section{Data Sources and Analytical Procedures}

In this section I describe the setting, participants, and procedures for analysis. Following this, I detail the findings of this study before discussing implications and considerations for teacher educators.

\section{Setting}


The setting for the study was an online course in pedagogy of writing instruction for teachers of EL students. The course, offered at a large Midwestern university, was part of a master's degree program in TESOL. As such, anyone pursuing this degree, or anyone with an interest in supporting EL learners in writing, was invited to take the course. The course content focused on themes and issues in the theory and practice of writing instruction for English learners. The main activities included discussion of readings and a learner case study. A primary goal of the course was to encourage students to examine historical practices of writing instruction for their relevance or appropriateness and to consider possibilities for implementing culturally appropriate writing practices (e.g., writing in students' home languages) in their classrooms. Course readings frequently took a critical orientation and focused on topics including learner identity, evaluation and feedback, the role of grammar, and genre-based approaches to writing instruction for EL students.

\section{Participants}

Definitions of "experienced" teachers vary, but most hinge on the number of years spent teaching. For example, Gatbonton (1999) and Tsui (2003) defined experienced teachers as having taught five or more years. For the purposes of this study, I have used their definition, focusing my analysis on the interactions of eight participant teachers, plus myself as the instructor. Participants' experience ranged from 5 - 30 years, and all were practicing K-12 or tertiary teachers at the time of the class. Their experience included K-12 and tertiary settings in the United States and Asia; participants included both native and non-native speakers of English. The following chart provides an overview of each participant included in the study, a brief description of their background provided by the participants during the first week of class, and the number of posts analyzed for each participant.

Table 1

Participants (all names are pseudonyms)

\begin{tabular}{llll}
\hline Participant & $\begin{array}{l}\text { Years' Experience } \\
\text { at Time of Study }\end{array}$ & $\begin{array}{l}\text { Teaching Context at } \\
\text { Time Study }\end{array}$ & $\begin{array}{l}\text { Number of } \\
\text { Posts }\end{array}$ \\
\hline Deanna & $\begin{array}{l}\text { 30 years as an } \\
\text { English teacher and } \\
\text { writing instructor }\end{array}$ & $\begin{array}{l}\text { English teacher/ } \\
\text { director of writing } \\
\text { tutorial program at } \\
\text { regional campus of } \\
\text { large university system }\end{array}$ & \\
& & 94 \\
\hline Erika & $\begin{array}{l}\text { Kindergarten EL } \\
\text { teacher in urban school } \\
\text { district; immigrated to }\end{array}$ & \\
\hline & EL years' & & \\
&
\end{tabular}




\begin{tabular}{|c|c|c|c|}
\hline & & $\begin{array}{l}\text { the United States as a } \\
\text { child }\end{array}$ & \\
\hline Bethany & 16 years' experience & $\begin{array}{l}\text { Kindergarten teacher in } \\
\text { urban school district } \\
\text { with large population of } \\
\text { EL students }\end{array}$ & 102 \\
\hline Mary & $\begin{array}{l}10 \text { years' } \\
\text { experience: } 6 \text { years } \\
\text { as lead EL teacher } \\
\text { in small district, } 4 \\
\text { years overseas }\end{array}$ & $\begin{array}{l}\text { Community college EL } \\
\text { teacher, currently } \\
\text { teaching one language } \\
\text { course }\end{array}$ & 68 \\
\hline Arjun & $\begin{array}{l}7 \text { years' experience: } \\
2 \text { years as teaching } \\
\text { assistant }+5 \text { years } \\
\text { overseas }\end{array}$ & $\begin{array}{l}\text { Teaching } \\
\text { assistant/translator in } \\
\text { urban school district; } \\
\text { recent immigrant to the } \\
\text { United States }\end{array}$ & 73 \\
\hline Angela & $\begin{array}{l}6 \text { years' experience/ } \\
5 \text { with EL students }\end{array}$ & $4^{\text {th }}$ grade EL teacher & 72 \\
\hline Linda & $\begin{array}{l}5 \text { years' experience: } \\
3 \text { as high school } \\
\text { Spanish teacher }+2 \\
\text { years overseas }\end{array}$ & $\begin{array}{l}\text { High school Spanish } \\
\text { teacher }\end{array}$ & 58 \\
\hline Jessica & $\begin{array}{l}5 \text { years' experience: } \\
4 \text { elementary } \\
\text { classroom teaching } \\
+1 \text { SPED }\end{array}$ & $\begin{array}{l}1^{\text {st }} \text { year as special } \\
\text { education (SPED) } \\
\text { teacher, few EL } \\
\text { students in district }\end{array}$ & 116 \\
\hline Instructor & $\begin{array}{l}6 \text { years' experience: } \\
3 \text { elementary } E L+3 \\
\text { years overseas }\end{array}$ & $\begin{array}{l}3^{\text {rd }} \text { semester teaching } \\
\text { writing pedagogy } \\
\text { course }\end{array}$ & 122 \\
\hline
\end{tabular}

\section{Data Analysis and Methodological Procedures}

Data were analyzed using the DP approach to discourse analysis, chosen for its emphasis on how participants account for, or make relevant claims to, psychological states such as belief. After approval from the institutional review board, I downloaded the forum discussion posts from one 15-week online course and entered them into ATLAS.ti (version 7), a qualitative data analysis software package. Following Potter and Wetherell's (1987) example, I began analysis by first engaging in multiple readings simply to see what was striking or "stood out." 
Analysis was iterative but can be described as involving in three phases. In the first phase, as I read the data, I created content-oriented memos to identify the topics related to teachers' beliefs repeatedly occurring in the data (e.g., beliefs about their teaching, beliefs about their students). Using memos as an audit trail (Creswell \& Miller, 2000), the focus on teachers' beliefs about CLD students was identified as an analytical focus. In phase two of analysis, each threaded conversation in which teachers' beliefs about CLD students were invoked was reread with the following questions modified from Potter (2004) in mind: what are they doing/accomplishing with their belief claims; how are they constructing their claims to achieve this; and what (linguistic) resources are being used to perform these belief claims? Throughout this second phase of data analysis, I kept memos focused on both discursive features (e.g., linguistic choice) and content (e.g., claims about "what students need"). These memos were used to supply codes for the data, in keeping with the theoretical and methodological approach for the study. Codes focused on what was being accomplished at a social level (e.g., accounting for particular teaching practices) and the ways that these claims were accomplished through particular discursive features. Finally, during the third phase of analysis, excerpts representative of the social functions and interactional patterns common across the data were identified for line-by-line explication.

\section{Warranting Analytical Claims}

As in all discourse analyses, demonstration of how interpretations were reached is provided in the findings by displaying how I reached my analytical conclusions through line-by-line analysis (Wood \& Kroger, 2000). In line with a DP approach to discourse analysis, findings are warranted through identifying alternative cases (Potter, 2004) - cases in the data that do not seem to fit the patterns-and by positioning my findings relative to other DP studies (Potter, 1996). This allowed me to shore up my claims by locating the current findings within existing research. Partial findings were shared with a critical friend at several points during the analysis, which helped to ensure that analytical claims were grounded in the data. Themes were also shared with participants for feedback. In keeping with a DP approach, this exchange was viewed as an opportunity to further understand teachers' constructions of EL students as interactionally situated. I attempted to maintain a reflexive stance throughout (Watt, 2007), aware that my interpretations are shaped for the occasion and framed by my orientation to the discursive aspects of beliefs construction.

\section{Findings}

All participants were experienced teachers, most of whom had also worked with CLD students $(n=7)$, though none aside from the instructor had completed a 
degree in teaching EL students. Through analysis, I found that their prior experience seemed to lead these teachers to make claims about EL students that both essentialized and overgeneralized their students' identities as learners. I demonstrate this through two discursive patterns observed across the data: by implicitly contrasting categories of "English language learner" with "native speaker" students and by aligning the needs of EL students with those of other "struggling" students (e.g., students in special education).

Analysis also revealed that participants managed their authority to speak about the needs of EL learners in patterned ways. In the section on "Accounting for Beliefs in Interaction," I illustrate how, although teachers typically levied their belief claims as based in their personal experiences, they also worked to distance themselves from being personally responsible for the "deficits" that characterized their students' struggles.

\section{Describing and Categorizing "EL Writers"}

Within the course, the focus of the weeks' discussions frequently turned to the needs of EL students. Participant-posed questions such as, "Have you found yourself, or co-workers, grading EL students' writing differently?" and "Should they be held to a different set of standards?" were clearly linked to responses that categorized or defined EL students. For instance, in response to the second question, Bethany replied:

\section{Excerpt 1:}

Growing up my mother would always tell me that "fair" didn't always mean equal, but did mean everyone getting what they needed. I believe that a majority of the professionals in my building recognize the cultural and linguistic differences that can affect how the EL student learns.

In this example, Bethany's belief claim about her colleagues' preparation to work with EL students comes in the form of an evaluative statement. She suggests that "a majority" of her colleagues "recognize the cultural and linguistic differences that can affect how the EL (English learner) student learns." In her response, she also makes an explicit claim contrasting EL student writers with another group of undifferentiated (and implicitly American) students. Further, the category of "the EL student" is offered in a straightforward way as those who have "cultural and linguistic differences that can affect how [they] learn." Despite this, Bethany provides little detail about those "differences." Though lacking specific details, Bethany's belief claim is presented as a factual account (Edwards \& Potter, 1992). Associating a particular group of people with a particular set of needs works as a commonsense practice of "mundane reasoning" (Watson, 2009, p. 41). In other words, by generalizing individual cultural and linguistic practices to a group of students ("the EL student") this extract illustrates a common way that experienced teachers in the class, while answering a question, simultaneously offered 
instruction to their classmates on how to understand and interpret the category of CLD learners.

\section{Categorizing EL Students as "Struggling" Learners}

Aligning the needs of EL student writers with "struggling" learners was another common way that participants characterized EL students. In the following example, Erica compares her students' challenges in meeting particular objectives to that of other "struggling" learners.

\section{Excerpt 2:}

Although my husband is not an ELL student, he did struggle all through school to meet objectives in his classes because of dyslexia. When he was in middle and high school there were some accommodations made for him, but not many. When it came to college, any accommodations he received before were no longer given. He struggled terribly, but not from lack of trying.... It's hard to know what is right... many of our ELL students receive accommodations that level the playing field for them until they get to college...something has to be done BEFORE college to help these students develop the strategies necessary to be as successful if the accommodations aren't going to be provided.

In this excerpt, Erica draws a comparison between her EL student and her husband, who "struggle[d] all through school... because of dyslexia." Authority to make this assessment is invoked by reference to her identity not as a teacher, but as a spouse. This invocation of authority functions to minimize disagreement both with her assessment that "something has to be done" and with the nearcomparison to students with dyslexia (like her husband). Moments of assessment, in which participants drew comparisons between students learning English and students with identified language disabilities, re-occurred throughout the data. For example, Jessica wrote:

\section{Excerpt 3:}

The first thing I noted from the article was even though this was talking about college level EL students, it could also work for all students. Many of the suggestions would have worked for my special ed students this year as well.

In contrast to the excerpt from Erica, Jessica's post clearly draws a connection between teaching practices for EL students presented in the reading and notions of "just good teaching" (Harper \& de Jong, 2004, p. 153) that would be appropriate for "all students." In the next sentence, she provides a "candidate answer" (Pomerantz, 1988, p. 360) for who "all students" might be, by adding that "the suggestions would have worked...for my special ed students," thereby leaving open the implication that strategies for "all students" are perhaps not quite for everyone, but rather for all groups of struggling learners. As Pomerantz (1988) 
noted, candidate answers can be proffered by participants as a way to guide potential respondents toward particular stances or to provide particular information. Thus, Jessica's suggestion that EL strategies are appropriate for "[her] special ed students" suggests to her classmates her familiarity with the subject and thereby strengthens the validity of her assessment.

\section{Accounting for Beliefs in Interaction}

Findings also show how participants' categorizations of EL students were frequently grounded in belief claims based upon their personal experiences. Although personal experiences were invoked, the claims themselves still often involved generalizations, rather than specific examples. For example, Mary wrote:

\section{Excerpt 4:}

From my experience, ELLs like to focus on spelling and grammar, but my thought is that they are doing so because this is something that has a 'rule' to go by. My ELLs love for me to say, "This is a rule." They want to learn the rules of English in order to do it "right."

As in this example, participants were found to mobilize their experience in order to ground their claims about EL students. Similar to Excerpt 1, Mary's claims about what EL students "like" ultimately work to delimit possibilities for understanding multilingual writers. In her characterization, multilingual writers "like to focus on spelling and grammar" and "want to learn the rules of English in order to do it "right." Further, the deictic "they" subtly but perceptibly differentiates multilingual writers from monolingual (native English-speaking) writers. Grounded in personal experience, participants' claims become easy to agree with, as objecting to the factuality of one's personal experiences is rare (Heritage \& Raymond, 2005). Interactionally, this construction works to relieve the other participants of responsibility to disagree. Since this categorization is based in her personal experience, it leaves open the possibility that it may not hold for everyone. At the same time, this situated characterization of multilingual students as preferring a particular sort of instruction-an instructional style that is focused on "rules" works to subtly enforce interpretations of teaching grounded in deficit models that emphasize rules-based instruction over other approaches, such as those that focus on developing creativity, for example.

On one hand, presenting facts with little or no evidence to support them may be explained by contextual factors: that most participants in the online class are familiar with, and have experience working with, EL students. However, the recurrence of this construction throughout the data also performed a social function in which categorizations like this become agreed-upon truths (Edwards, 1997). In other words, by constructing their statements about EL students as factual claims, participants' categorizations become 'real' or 'common knowledge' to the participants in the course. 


\section{Binaries in Teachers' Accounts of their Beliefs}

In addition to generalizations, participants also frequently used their personal experiences to construct binaries in belief statements about EL students. These binaries, like categorizations in general, were often implicit rather than explicit. Both mentioned and unmentioned categories, through generalizations, index groups of students as particular types of learners. Excerpt 5 , from Angela, a 6 -year veteran teacher, provides an example of this pattern.

\section{Excerpt 5:}

While teaching fourth grade, I have discovered that ESL students are at a critical stage in their writing development. It seems to me that a majority of the students are "scared" to take a risk with their writing. I see this as a major problem faced by ESL students in writing. They are always so wrapped up in correct spelling that they focus more on the mechanics than the content of their writing. Because they have this obstacle, ESL students tend to take less risks as writers. In fact, I did a writing exercise with my students today and I probably had a third of my class asking how to spell a word. This is something I address every year. I teach that although spelling is important, it is not the most important thing. The most important thing about writing is the ideas.

In this representative excerpt, Angela presents "truths" about English as a second language (ESL) students, grounding her "discovery" about the nature of EL students from her experience as a fourth-grade teacher. By first basing her claims about learners in her experience, she paves the way for many factual claims to follow: "ESL students are at a critical stage"; they are "scared to take a risk"l they are "always so wrapped up in correct spelling"; and they "take less risks [sic] as writers" because of this. In working up categories like this, there is also an implicit comparison between EL (ESL) students and other (non-ESL, native English speaking) students, because making differentiating statements occurs against a backdrop of assumptions about what is "normal" or "expected." This implicit contrast becomes even more evident in this example with the use of the evaluative lexical item "less" to describe the risks that EL students take as writers, clearly marking the implicit comparison to (non-EL) students who take "more" risks. As Baker (1997) suggested, "the attributions that are hinted at are as important as any stated in so many words" (p. 142).

The production of binary categories in Angela's response, as observed across the data, was typically grounded in teachers' prior experience. Angela's claim to have "discovered" this information in her work of "teaching fourth grade" is a prime example. Similar constructions were found across the data. For example, Jessica wrote: 


\section{Excerpt 6:}

I do feel educators treat L1 students writing as the norm, and I don't know if I think this is wrong.... As an ESL teacher, I have always valued my student's first language, and encourage the development of both languages when possible.

Here Jessica asserts that she values her "student's first language," a norm that is expected of EL teachers, but she tempers her asset-oriented statement with the modifier "when possible." This statement is in direct contradiction to her opening statement that it may not be wrong to "treat L1 [native English speaking] students' writing as the norm." Further, teachers' epistemic primacy to such knowledge was foregrounded by this framing. In other words, because teachers grounded their categorizations of EL students in their personal experience, the claims were more difficult for other participants to potentially disagree with, as people tend not to contradict statements of fact made by those with first-hand access to the persons or events under discussion (Raymond \& Heritage, 2006).

Interpreting across the data, analysis revealed an overall pattern wherein participants worked to accountably define EL students based on their prior experience, and these categories were rarely contradicted by other teachers. This is visible in the way that Jessica characterizes her stance "as an ESL teacher" as someone who has "always valued [her] students' first languages." Thus, although there is evidence in experienced teachers' writing for the need to understand differences of CLD students positively, teachers still often reproduced dominant discourses in their statements of beliefs (Shim, 2014).

\section{Discussion and Implications}

When experienced teachers seek EL teaching certification, teacher educators must consider how these teachers' prior experiences may play a role in their interactions in the teacher education classroom. Teachers' beliefs about working with CLD students are an important aspect of teaching to and for diversity (Gay, 2010; Palmer \& Henderson, 2016). As previous studies have shown, personal experiences played a large role in teachers' statements of belief (Pajares, 1992). These teachers drew on their personal experience when crafting statements of belief about EL students' strengths, needs, and capabilities. Further, assessments of EL students' abilities were typically couched to distance the teachers from negative labeling. Their claims were nonspecific enough that they also worked to minimize potential disagreement from their classmates regarding any controversial claim (Pomerantz, 1984). This generic vagueness (Potter, 1996) observed across the data also hints at the delicate nature of the task of discussing one's work with an audience of peers and instructor.

The findings suggest a disconnect between teachers' prior experiences and ways of talking introduced in EL teacher education courses. Similar to Shim (2014), findings suggest that experienced teachers draw on asset-oriented stances in line 
with CLD pedagogy, while simultaneously reproducing dominant discourses. For example, inservice teachers take up asset-oriented stances within class discussions, while at other times drawing upon less asset-oriented stances, such as treating English as the "norm." Unlike Doran's (2017) finding that teachers remain unfamiliar with concepts in CLD teaching after learning, this study finds that teachers at times display familiarity with these concepts, but struggle to take them up consistently. The shifting ways that experienced teachers construct their teaching practice are implicated in the need to manage their own identities as experienced teachers while still exhibiting the qualities of a CLD educator. The local task of categorizing and constructing the identities of EL students occurred not intentionally, but as an unintended consequence of enacting their roles as "experienced teachers" in the online class. That is, teachers in the class faced the dilemma of being both an experienced teacher and a learner simultaneously.

Finally, findings show that teachers engaged in categorization practices that relied on generalization and the implicit construction of binaries. Through this, teachers' belief statements imbued EL students with particular, sometimes limiting, characteristics. In particular, claims about EL students were often made against an invisible backdrop differentiating ELs from what it is to be "mainstream" students in school. In constructing these categorizations, experienced teachers often relied upon their personal experience to justify the claims that they made. Viewed across the dataset, the coupling of claims of their own personal experience with statements about EL students' needs or capabilities proved to have a "strongly reifying impact" (Mazeland \& Berenst, 2008, p. 58). Many of these binaries worked to create an overall repertoire of difference, where EL students were contrasted with their "mainstream" counterparts. Perhaps most interestingly, the teachers' characterizations often focused on the needs or perceived "struggles" of EL students. Teachers' characterizations of students and the impact of these descriptive practices on students' learning have been studied extensively (e.g., Baker, 1997; Brophy \& Good, 1986). This study adds the finding that teachers' belief claims regarding EL students were often provided alongside demonstrations of their personal experience or expertise. That is, teachers' claims played a role more as a display of their experience than as an intentional claim of belief.

\section{Conclusion}

Graduate-level programs for inservice teachers have the "potential to challenge and change teacher beliefs and practices about language when it is ongoing and directly relevant to the content teachers are teaching" (DiCerbo, Anstrom, Baker, \& Rivera, 2014, p. 29). Therefore, identifying instances of positioning or categorization as experienced teachers engage in them is important to EL teacher preparation because it is in these moments that teacher educators have the opportunity to help inservice teachers challenge their linguistic practices. It is not enough just to engage in assets-based talk about students or to model it (Gleeson \& Davidson, 2016). Rather, it may be more instructive to provide teacher- 
learners with opportunities to identify categorizations within their own constructions and create occasions to re-construct such talk. By focusing on the ways in which teachers' constructions of EL students are socially and contextually contingent, teacher educators can gain a better understanding of how these constructions are worked up by participants at the time and place of their use. In this way, we can avoid putting "negative assumptions and ideologies...front and center" in teacher education and professional development (English, 2009, p. 489). This study suggests that by orienting to beliefs as contingent, teacher educators might avoid assumptions reifying the claims that pre-service and inservice teachers may make in class and instead productively engage their students in conversation about the production of beliefs in context.

\section{References}

Ardasheva, Y., \& Brown, S. (2011), Content-area teachers seeking ELL preparation: What motivates them? Career Educator Quarterly, 1(1), pp. 1741. Retrieved from http://www.eric.ed.gov/PDFS/ED524512.pdf

Baker, C. (1997). Membership categorization and interview accounts. In D. Silverman (Ed.), Qualitative research: Theory, method and practice (pp. 130-143). Thousand Oaks, CA: Sage.

Ballantyne, K.G., Sanderman, A. R., \& Levy, J. (2008), Educating English language learners: Building teacher capacity. Washington, DC: National Clearinghouse for English Language Acquisition.

Barker, D. M., \& Rossi, A. (2012). The trouble with teamwork: A discursive investigation. Physical Education \& Sport Pedagogy, 17(1), 1-19. doi:10.1080/17408989.2010.535198

Barker, D. M., \& Rossi, A. (2011). Understanding teachers: The potential and possibility of discourse analysis. Sport, Education and Society, 16(2), 139158. doi:10.1080/13573322.2011.540421

Borg, S. (2011). The impact of in-service teacher education on language teachers' beliefs. System, 39(3), 370-380. doi:10.1016/j.system.2011.07.009

Brophy, J., \& Good, T. (1986). Teacher behavior and student achievement. In M. Wittrock (Ed.), Handbook of research on teaching (pp. 328-375). New York, NY: Macmillan.

Bryan, L. A., \& Atwater, M. M. (2002). Teacher beliefs and cultural models: A challenge for science teacher preparation programs. Science Education, 86(6), 821-839. doi: 10.1002/sce.10043

Chu, S. Y., \& Garcia, S. (2014). Culturally responsive teaching efficacy beliefs of in-service special education teachers. Remedial and Special Education, 35(4), 218-232. doi:10.1177/0741932513520511 
Coady, M., Harper, C., \& de Jong, E. J. (2011). From preservice to practice: Mainstream elementary teacher beliefs of preparation and efficacy with English language learners in the state of Florida. Bilingual Research Journal, 34(2), 223-239. doi: 10.1080/15235882.2011.597823

Coady, M. R., Harper, C. A., \& de Jong, E. J. (2016). Aiming for equity: Preparing mainstream teachers for inclusion or inclusive classrooms? TESOL Quarterly, 50(2), 340-368. doi:10.1002/tesq.223

Creswell, J. W., \& Miller, D. L. (2000). Determining validity in qualitative inquiry. Theory into Practice, 39(3), 124-130. Retrieved from http://dx.doi.org/10.1207/s15430421tip3903_2

Daniel, S. M., \& Pray, L. (2016). Learning to teach English language learners: A study of elementary school teachers' sense-making in an ELL endorsement program. TESOL Quarterly, 51(4), 787-819. doi:10.1002/tesq.347

de Courcy, M. (2011). I thought it would be just like mainstream: Learning and unlearning in the TESOL practicum. TESOL in Context, 21(2), 23-33. Retrieved from http://search.informit.com.au/documentSummary; $\mathrm{dn}=079925055931430 ;$ res=IELHSS

de Jong, E. J., Harper, C. A., \& Coady, M. R. (2013). Enhanced knowledge and skills for elementary mainstream teachers of English language learners. Theory into Practice, 52(2), 89-97. doi:10.1080/00405841.2013.770326

DiCerbo, P. A., Anstrom, K. A., Baker, L. L., \& Rivera, C. (2014). A review of the literature on teaching academic English to English language learners. Review of Educational Research, 84(3), 446-482. doi:10.3102/ 0034654314532695

Doran, P. R. (2017). Teachers' self-reported knowledge regarding English learners: Perspectives on culturally and linguistically inclusive instruction and intervention. International Journal of Inclusive Education, 21(5), 557572. doi:10.1080/13603116.2016.1218949

Edwards, D. (1997). Discourse and cognition. London, United Kingdom: Sage.

Edwards, D., \& Potter, J. (1992). Discursive psychology. Newbury Park, CA: Sage Publications.

Edwards, D., \& Potter, J. (2001). Discursive psychology. In A. W. McHoul \& M. Rapley (Eds.), How to analyze talk in institutional settings: A casebook of methods (pp. 12-24). London, United Kingdom: Continuum.

English, B. (2009). Who is responsible for educating English language learners? Discursive construction of roles and responsibilities in an inquiry community. Language and Education, 23(6), 487-507. doi:10.1080/ 09500780902954216

Fives, H., \& Buehl, M. (2012). Spring cleaning for the 'messy' construct of teachers' beliefs: What are they? Which have been examined? What can they tell us? In K. Harris, S. Graham, \& T. Urdan (Eds.), APA educational psychology 
handbook: Vol. 2. Individual differences and cultural contextual factors (pp. 471 - 499). Washington, DC: American Psychological Association.

Flores, B. B., \& Smith, H. L. (2009). Teachers' characteristics and attitudinal beliefs about linguistic and cultural diversity. Bilingual Research Journal, 31(1-2), 323-358. doi: 10.1080/15235880802640789

Freeman, D. (1996). 'To take them at their word': Language data in the study of teachers' knowledge. Harvard Educational Review, 66(4), 732-762. http://dx.doi.org/10.17763/ haer.66.4.3511321j38858h69

Freeman, D., \& Johnson, K. E. (1998). Reconceptualizing the knowledge-base of language teacher education. TESOL Quarterly, 32(3), 397-417. doi: $10.2307 / 3588114$

Gándara, P., Maxwell-Jolly, J., \& Driscoll, A. (2005). Listening to teachers of English language learners: A survey of California teachers' challenges, experiences, and professional development needs. Santa Cruz, CA: Center for the Future of Teaching and Learning.

Gatbonton, E. (1999). Investigating experienced ESL teachers' pedagogical knowledge. Modern Language Journal, 83(1), 35-50. http://dx.doi.org/ $10.3138 / \mathrm{cmlr} .56 .4 .585$

Gatbonton, E. (2008). Looking beyond teachers' classroom behavior: Novice and experienced ESL teachers' pedagogical knowledge. Language Teaching Research, 12(2), 161-182. doi: 10.1177/1362168807086286

Gay, G. (2010). Acting on beliefs in teacher education for cultural diversity. Journal of Teacher Education, 61(1-2), 143-152. doi:10.1177/0022487109347320

Gay, G. (2014). Teachers' beliefs about cultural diversity: Problems and possibilities. In H. Fives \& M. G. Gill (Eds.), International handbook of research on teachers' beliefs (pp. 436-452). London, United Kingdom: Routledge.

Gleeson, M., \& Davison, C. (2016). A conflict between experience and professional learning: Subject teachers' beliefs about teaching English language learners. RELC Journal, 47(1), 43-57. doi: 10.1177/0033688216631221

Harper, C. A., \& de Jong, E. J. (2004). Misconceptions about teaching Englishlanguage learners. Journal of Adolescent \& Adult Literacy, 48(2), 152-162. doi: 10.1598/JAAL.48.2.6

Heritage, J., \& Raymond, G. (2005). The terms of agreement: Indexing epistemic authority and subordination in talk-in-interaction. Social Psychology Quarterly, 68(1), 15-38. doi: 10.1177/019027250506800103

Hertzog, L. (2011). Can a successful ESL teacher hold deficit beliefs of her students' home languages and cultures? Multicultural Perspectives, 13(4), 197-204. doi: 10.1080/15210960.2011.616829

Jimenez-Silva, M., Olson, K., \& Hernandez, N. J. (2012). The confidence to teach English language learners: Exploring coursework's role in developing 
preservice teachers' efficacy. The Teacher Educator, 47(1), 9-28. doi:10.1080/08878730.2011.632471

Johnson, K. E. (1994). The emerging beliefs and instructional practices of preservice English as a second language teachers. Teaching and Teacher Education, 10(4), 439-452. doi: 10.1016/0742-051X(94)90024-8

Karabenick, S. A., \& Noda, P. A. C. (2004). Professional development implications of teachers' beliefs and attitudes toward English language learners. Bilingual Research Journal, 28(1), 55-75. http://dx.doi.org/10.1080/ 15235882.2004.10162612

Kyles, C., \& Olafson, L. (2008). Uncovering preservice teachers' beliefs about diversity through reflective writing. Urban Education, 43, 500-518. doi:10.1177/0042085907304963

Lester, J. N. (2011). Exploring the borders of cognitive and discursive psychology: A methodological reconceptualization of cognition and discourse. Journal of Cognitive Education and Psychology, 10(3), 280-293. doi: 10.1891/19458959.10.3.280

Lucas, T., \& Villegas, A. M. (2013). Preparing linguistically responsive teachers: Laying the foundation in preservice teacher education. Theory into Practice, 52(2), 98-109. doi:10.1080/00405841.2013.770327

Lucas, T., Villegas, A. M., \& Martin, A. D. (2014). Teachers' beliefs about English language learners. In H. Fives \& M. G. Gill (Eds.), International handbook of research on teachers' beliefs (pp. 453-474). London, United Kingdom: Routledge.

Mazeland, H., \& Berenst, J. (2008). Sorting pupils in a report-card meeting: Categorization in a situated activity system. Text \& Talk, 28(1), 55-78. doi:10.1515/TEXT.2008.003

Oreshkina, M., \& Lester, J. N. (2015). A discursive psychology approach to the study of pre-service teachers' written reflections about teacher effectiveness. Teaching Education, 26(4), 422-438. doi:10.1080/ 10476210.2015.1034680

Pajares, M. F. (1992). Teachers' beliefs and educational research: Cleaning up a messy construct. Review of Educational Research, 62(3), 307-332. doi: 10.3102/00346543062003307

Palmer, D. K., \& Henderson, K. I. (2016). Dual language bilingual education placement practices: Educator discourses about emergent bilingual students in two program types. International Multilingual Research Journal, 10(1), 17-30. doi:10.1080/19313152.2015.1118668

Pandya, C., Batalova, J., \& McHugh, M. (2011). Limited English proficient individuals in the United States: Number, share, growth, and linguistic diversity. Washington, DC: Migration Policy Institute. 
Pettit, S. K. (2011). Teachers' beliefs about English language learners in the mainstream classroom: A review of the literature. International Multilingual Research Journal, 5(2), 123-147. doi:10.1080/19313152.2011.594357

Polat, N. (2010). A comparative analysis of pre-and in-service teacher beliefs about readiness and self-competency: Revisiting teacher education for ELLs. System, 38(2), 228-244. doi: 10.1016/j.system.2010.03.004

Pomerantz, A. (1984). Agreeing and disagreeing with assessments: Some features of preferred/dispreferred turn shapes. In J. M. Atkinson \& J. Heritage (Eds.), Structures of social action: Studies in conversation analysis (pp. 57-101). Cambridge, United Kingdom: Cambridge University Press.

Pomerantz, A. (1988). Offering a candidate answer: An information seeking strategy. Communications Monographs, 55(4), 360-373.

Potter, J. (1996). Representing reality: Discourse, rhetoric and social construction. London, United Kingdom: Sage.

Potter, J. (2004). Discourse analysis. In M. H. Ma \& A. Bryman (Eds.), Handbook of data analysis (pp. 607-624). London, United Kingdom: Sage.

Potter, J. (2012). Discourse analysis and discursive psychology. In H. Cooper (Ed.), APA handbook of research methods in psychology: Quantitative, qualitative, neuropsychological and biological (Vol. 2, pp. 111-130). Washington. DC: American Psychological Association Press.

Potter, J., \& Hepburn, A. (2008). Discursive constructionism. In J. A. Holstein \& J. F. Gubrium (Eds.), Handbook of constructionist research (pp. 275-293). New York, NY: Guilford Press.

Potter, J., \& Wetherell, M. (1987). Discourse and social psychology: Beyond attitudes and behavior. London, United Kingdom: Sage.

Raymond, G., \& Heritage, J. (2006). The epistemics of social relations: Owning grandchildren. Language in Society, 35(05), 677-705. doi:10.1017/S0047404506060325

Reeves, J. R. (2006). Secondary teacher attitudes toward including Englishlanguage learners in mainstream classrooms. The Journal of Educational Research, 99(3), 131-143. doi: 10.3200/JOER.99.3.131-143

Rizzuto, K. C. (2017). Teachers' perceptions of ELL students: Do their attitudes shape their instruction? The Teacher Educator, 52(3), 182-202. doi:10.1080/08878730.2017.1296912

Sacks, H. (1992). Lectures on conversation (Vol 1). Cambridge, MA: WileyBlackwell.

Shim, J. M. (2014). A Bourdieuian analysis: Teachers' beliefs about English language learners' academic challenges. International Journal of Multicultural Education, 16(1), 40-55. http://dx.doi.org/10.18251/ ijme.v16i1.783 
Tsui, A. B. (2003). Understanding expertise in teaching: Case studies of ESL teachers. New York, NY: Cambridge University Press.

Warren, A. N. (2018). The social functions of teachers' beliefs in an online class. Teaching Education, 1-18. doi: https://doi.org/10.1080/ 10476210.2018.1445217

Watson, R. (1997). Some general reflections on 'categorization and 'sequence' in the analysis of conversation. In S. Hester \& P. Eglin (Eds.), Culture in action: Studies in membership categorization analysis (pp. 49-75). Washington, DC: International Institute for Ethnomethodology and Conversation Analysis and the University Press of America.

Watson, R. (2009). Analysing practical and professional texts: A naturalistic approach. Surrey, UK: Ashgate.

Watt, D. (2007). On becoming a qualitative researcher: The value of reflexivity. The Qualitative Report, 12(1), 82-101. Retrieved from http://nsuworks.nova.edu/tqr/vol12/iss 1/5/

Webster-Wright, A. (2009). Reframing professional development through understanding authentic professional learning. Review of Educational Research, 79, 702-739. doi:10.3102/0034654308330970

Wetherell, M. (1998). Positioning and interpretative repertoires: Conversation analysis and post-structuralism in dialogue. Discourse \& Society, 9(3), 387412. doi:10.1177/0957926598009003005

Wood, L. A., \& Kroger, R. O. (2000). Doing discourse analysis: Methods for studying action in talk and text. Thousand Oaks, CA: Sage.

\section{Author Contact}

Amber N. Warren: amberwarren@unr.edu

Literacy, Language \& Culture, 1664 N. Virginia St, College of Education / MS0299

Reno, Nevada 89557 U. S. A. 


\section{Appendix A:}

Table of Example Extracts for Codes Illustrated in the Findings

Example Extracts from Data

\section{Pattern 1: Categorizing EL Learners}

Sub-pattern 1: Contrasting EL and native language peers

- In my classroom, I encourage all students to share orally, but many are hesitant to do so. After all, public speaking is a huge fear for all of us, but this is especially true of my ELLs because they don't want to appear illiterate or ignorant in front of their peers.

- Essentially, because mainstream teachers believe ESL students struggle with writing more, they are more lenient on the grading policies, especially when it comes to grammar.

- I think that there are many times when students need to be evaluated commonly because it gives comparison data which can be valuable in developing lessons and guiding instruction. On the other hand, I can also see benefits of grading an EL student at their 'just right level.'

Sub-pattern 2: ELs as "struggling"

- For many EL students learning to write fluently is much more challenging than learning to speak fluently. Written communication usually comes much more slowly, but is essential for ESL students, especially those in higher education programs.

- Like with SPED, I also see academic or content-specific language to be a major obstacle for ELLs. This is the hardest language to teach and acquire, but is probably the most important for students who are mainstreamed or submerged into standard subjects and courses.

- The first thing I noted from the article was even though this was talking about college level EL students, it could also work for all students. Many of the suggestions would have worked for my special ed students this year as well.

- I too agree, comparing students to other students is a horrible idea. Everybody is different and learn or succeed differently. Unfortunately, we do it all the time. Not just with our EL students, but with everything else as well. I know with my special education students, we are constantly saying, "In comparison to same age peers." I just don't see another way around it. 


\section{Pattern 2: Accounting for Beliefs in Personal Experience}

- Few of my school-aged ELLs wanted to or could articulate their feelings about how the sacrifice and obvious strong desires of their parents affects how they view education. Do they feel grateful and motivated to work harder, are they resentful of the stress and pressure, or are they simply not aware of such "meta" thinking?

- From my own experiences, children that come from parents with a humble educational background, like many ELL students, do not get the needed academic stimulation or support as their peers.

- From my experience, my ELLs like to focus on spelling and grammar, but my thought is that they are doing so because this is something that has a 'rule' to go by. My ELLs love for me to say, 'This is a rule.' 